\title{
A new species of the genus Pyrophleps Arita et O. Gorbunov, 2000 (Lepidoptera: Sesiidae) from Laos, with remarks on the genus
}

\author{
Новый вид рода Pyrophleps Arita et O. Gorbunov, 2000

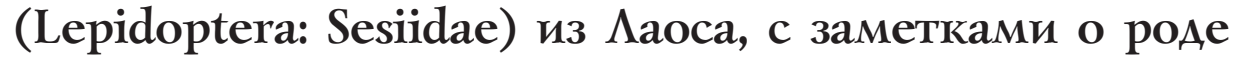

\author{
O.G. Gorbunov \\ О.Г. Горбунов
}

\begin{abstract}
A.N. Severtsov Institute of Ecology and Evolution, Russian Academy of Sciences, Leninsky prospekt 33, Moscow 119071, Russia. E-mail: gorbunov.oleg@mail.ru

Институт проблем экологии и эволюции им. А.Н. Северцова РАН, Ленинский проспект, 33, Москва 119071, Россия.
\end{abstract}

KEY WORDS. Osminiini, clearwing moths, new species, Oriental Region.

КЛЮЧЕВЫЕ СЛОВА. Osminiini, бабочки-стеклянницы, новый вид, Ориентальный регион.

ABSTRACT A redescription of the genus Pyrophleps Arita et O. Gorbunov, 2000 and a description of the new species Pyrophleps zamesovi sp.n. from Laos is presented. The holotype of the new species is deposited in the collections of the A.N. Severtsov Institute of Ecology and Evolution of the Russian Academy of Sciences, Moscow, Russia. Female and the larval host plant of the new species are unknown.

РЕЗЮМЕ. Приведено переописание рода Pуrophleps Arita et O. Gorbunov, 2000 и описание нового вида Pyrophleps zamesovi sp.n. из Лаоса. Голотип нового вида хранится в коллекции Института проблем экологии и эволюции им. А.Н. Северцова Российской академии наук в Москве. Самка и кормовое растение гусениц неизвестны.

\section{Introduction}

Despite the intensification of research on the fauna of clearwing moths (Sesiidae) in Southeast Asia in the last couple of decades [Arita, Gorbunov, 2000a, b, 2001, 2002, 2003; Gorbunov, Arita, 2000, 2001, 2002, 2005, 2018, 2019, 2020a-c; Kallies, Arita, 2001, 2004a, b, 2005, 2006; Gorbunov, 2015a, b, 2018, 2021a, b], the degree of its knowledge should be considered extremely low. This fully applies to Laos. Only nine sesiid species are known from the country for the time being [Arita et al., 2019; Arita, Gorbunov, 2000a; Gorbunov, 2015b, 2021a, b; Kallies, Štolc, 2018; Kallies et al., 2020].

In their recent publication, Kallies and Štolc [2018] synonymized the genus Pyrophleps Arita et O. Gorbunov, 2000 with the genus Aschistophleps Hampson, 1893. I pointed out the erroneousness of this nomencla- tural act, restored the genus Pyrophleps from synonyms and described a new genus [Gorbunov, 2021a]. Here I can only add that with the mentioned nomenclatural act of synonymization of the genus Pyrophleps, neither representatives of the genus Aschistophleps nor of the genus Pyrophleps were dealt with.

A very successful expedition to Laos in 2005 resulted in the collection of a great number of clearwing moths [Gorbunov, 2015b]. After a detailed study, one representative of the genus Pyrophleps turned out to be a new species. Now, having at hand three species of this genus, I can somewhat clarify the diagnosis of the genus.

Below is a redescription of the genus Pyrophleps and a description of the new species Pyrophleps zamesovi sp.n. This is my fourth report on the results of a very successful 2005 expedition to Laos [Gorbunov, 2015, 2021a, b].

The description is made using a Leica EZ4 stereomicroscope with LED illuminations, and images is taken with a Sony ${ }^{\circledR} \alpha 450$ DSLR camera equipped with a Minolta $^{\circledR} 50 \mathrm{f} / 2.8$ Macro lens. The head figures are taken with a Keyence $\mathbb{R}$ VHX-1000 Digital Microscope, but these of the genitalia are taken with a Keyence ${ }^{\circ}$ BZ9000 Biorevo Fluorescence Microscope. The processing of all illustrations is finalized with the Adobe ${ }^{\circledR}$ Photoshop $^{\circledR}$ CC 2020 software.

All labels of the holotype are cited verbatim. The labels of geographical data, imaging data and genitalia preparation numbers are printed on white paper, but the type label is printed on red paper. Each label is separated by a semicolon ";" lines in a label are separated by a slash "/". All pictures of the specimens are labeled with a number, consisting of letters and digits: name of the family, two consecutive digits separated by $n$-dash and a year following m-dash (e.g. SESI-

How to cite this article: Gorbunov O.G. 2021. A new species of the genus Pyrophleps Arita et O. Gorbunov, 2000 (Lepidoptera: Sesiidae) from Laos, with remarks on the genus // Russian Entomol. J. Vol.30. No.2. P.166174. doi: 10.15298/rusentj.30.2.10 
IDAE pictures №№ 0017-0018-2020). These letter and digit codes correspond to the numbering system of the figured specimens in the author's archive. The genitalia preparation is stored in a microtube with glycerol and pinned under the specimen. The dissected genitalia are equipped with the corresponding number placed in the microtube. This number as a label (e. g. Genitalia preparation № OG-006-2021) is pinned under the specimen and is listed in the archives of the author.

The type material of the new species is kept in the collection of the A.N. Severtsov Institute of Ecology and Evolution of the Russian Academy of Sciences, Moscow, Russia (COGM).

The names of plants are given in accordance with The Plant List [2013].

\section{Taxonomic account}

Pyrophleps Arita et O. Gorbunov, 2000

"Pyrophleps Arita \& Gorbunov, gen. nov." - Arita, Gorbunov, 2000: 64. Type species: Pyrophleps nigripennis Arita et O. Gorbunov, 2000, by original designation.

LITERATURE. Pühringer, Kallies, 2004: 19 (Pyrophleps); Xu et al., 2015: 151 (Pyrophleps); Skowron et al., 2015: 426 (Pyroph leps); Skowron Volponi, Volponi, 2017: 129, 130 (Pyrophleps); Kallies, Štolc, 2018: 596, 599 (as a synonym of Aschistophleps Hampson, 1893); Pühringer, Kallies, 2021 (as a synonym of Aschistophleps Hampson, 1893).

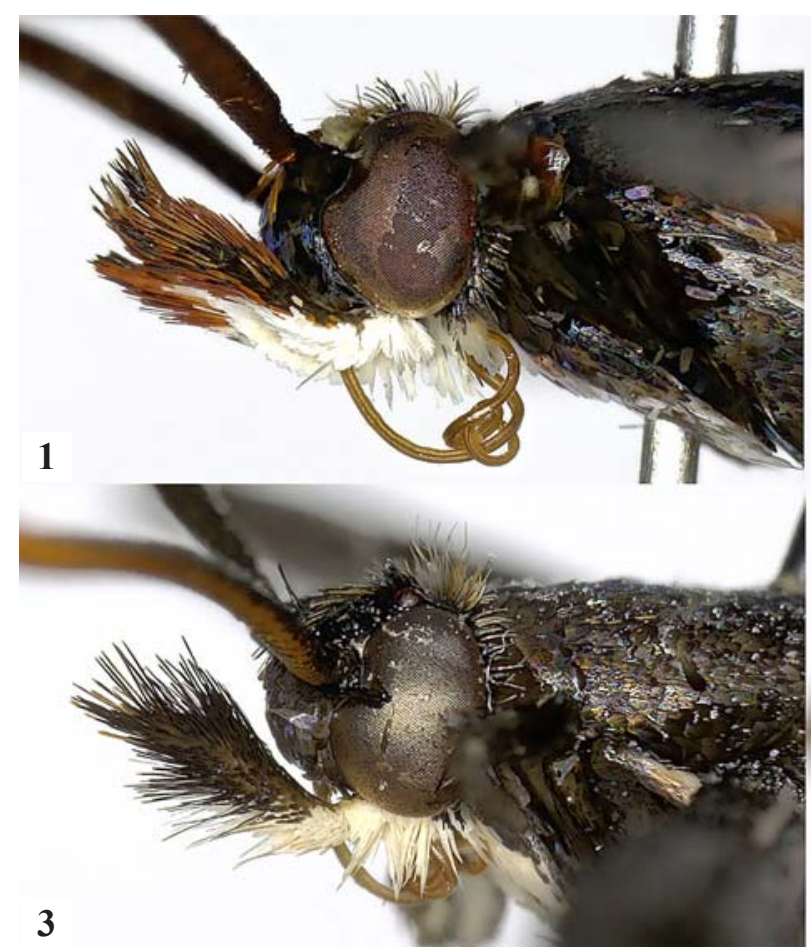

REDESCRIPTION. Brightly-coloured, small-sized, longlegged clearwing moths with alar expanse 13-19 mm. Superficially resembling the genus Aschistophleps Hampson, 1893.

Head with antenna strongly clavate, without cilia in male; frons smooth-scaled; labial palpus (Figs 1-4) long, directed ahead, tufted with long hair-like scales on mid joint; compound eyes distinctly bean-shaped; proboscis well-developed, long, functional; vertex covered with short hair-like scales. Thorax smooth-scaled, both metepimeron and metameron with long hair-like scales posteriorly. Fore tibia tufted with long hair-like scales at posterior margin; hind leg with distal half of tibia and 1-2 basal tarsomeres tufted with long hair-like scales. Abdomen smooth-scaled, anal tuft nearly undeveloped. Forewing with transparent areas rather well-developed, cells of external transparent area divided into two cells by a scaled line; veins $R_{1}$ and $R_{2}$ parallel, veins $R_{3+4}$ and $R_{5}$ arising from a common point. Hindwing transparent, discal spot narrow, reaching base of vein $\mathrm{M}_{3}$; vein $\mathrm{M}_{3}$ arises from vein $\mathrm{CuA}_{1}$ slightly basal to cross-vein.

MALE GENITALIA (Figs 23-26). Uncus with a semioval plate of long hair-like setae lateral-apically, covering tuba analis like a collar; gnathos narrow, long, distinctly protruding caudally; valva gradually widens towards the center, and then narrows rather sharply towards the apex, making distal half spear-shaped, densely covered with short and very thin hair-like setae; saccus short but broad, about as long as vinculum, straight basally; aedeagus relatively long, about 1.5 times as long as valva; vesica with numerous, minute cornuti.

FEMALE. Unknown.

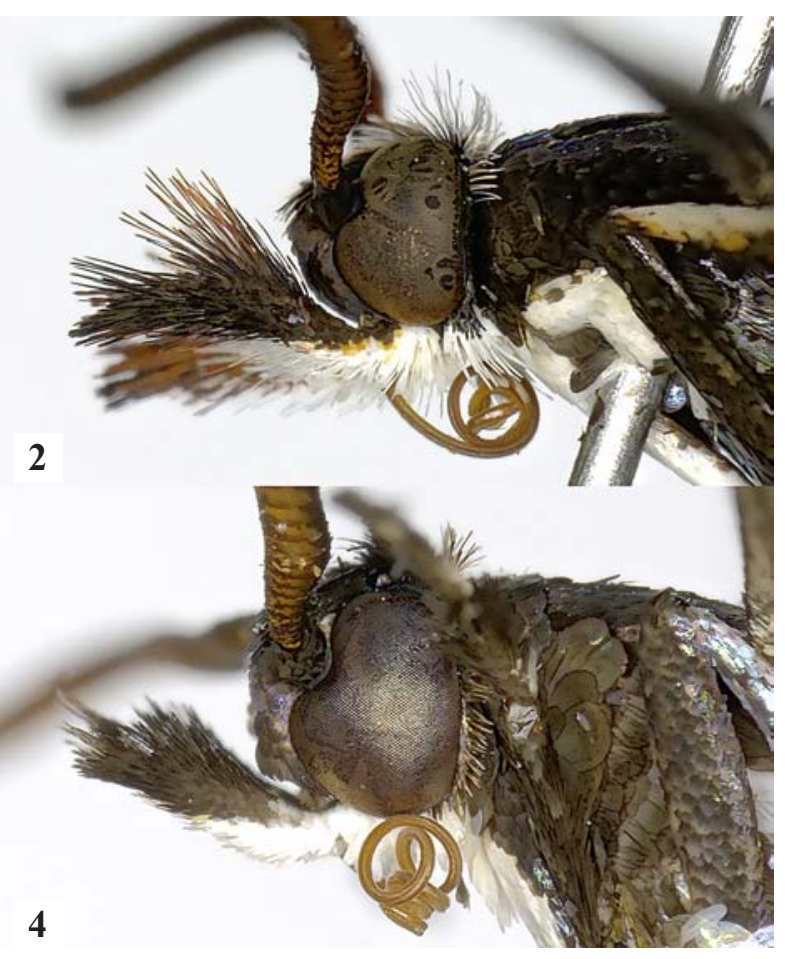

Figs 1-4. Labial palpus of Pyrophleps spp. 1 - P. zamesovi sp.n., holotype. Sesiidae picture № 0107-0108-2021; 2 - P. zamesovi sp.n., paratype. Sesiidae picture № 0095-0096-2021; 3 - P. nigripennis Arita et O. Gorbunov, 2000, paratype. Sesiidae picture № 0113-01142021; 4 - P. vitripennis Arita et O. Gorbunov, 2000, paratype. Sesiidae picture № 0121-122-2021.

Рис. 1-4. Губные щупики Pуrophleps spp. 1 - P. zamesovi sp.n., голотип. Sesiidae снимок № 0107-0108-2021; 2 - P. zamesovi sp.n., паратип. Sesiidae снимок № 0095-0096-2021; 3 - P. nigripennis Arita et O. Gorbunov, 2000, паратип. Sesiidae снимок № 01130114-2021; $4-P$. vitripennis Arita et O. Gorbunov, 2000, паратип. Sesiidae снимок № 0121-122-2021. 

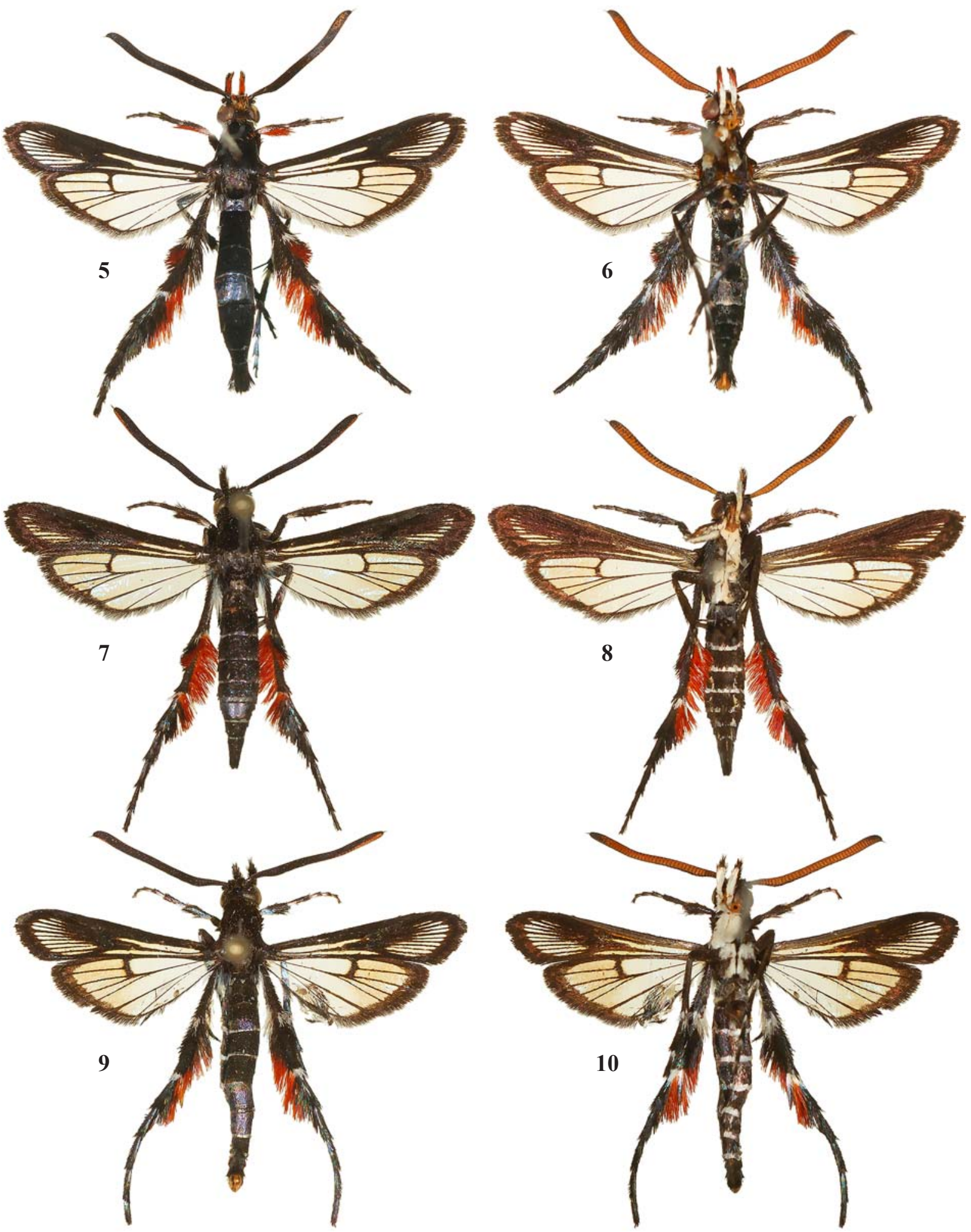

Figs 5-10. Pyrophleps spp. 5-P. zamesovi sp.n., holotype, upside. Sesiidae picture № 0107-2021. Alar expanse $18.9 \mathrm{~mm} ; 6$ - ditto underside. Sesiidae picture № 0108-2021; 7 - P. nigripennis Arita et O. Gorbunov, 2000, paratype. Sesiidae picture № 0113-2021. Alar expanse $19.3 \mathrm{~mm}$ (COGM); 8 - ditto underside. Sesiidae picture № 0114-2021; 9 - P. vitripennis Arita et O. Gorbunov, 2000, paratype. Sesiidae picture № 0121-2021. Alar expanse 18.4 mm (COGM); 10 — ditto underside. Sesiidae picture № 0122-2021.

Рис. 5-10. Pyrophleps spp. 5 - P. zamesovi sp.n., голотип, сверху. Sesiidae снимок № 0107-2021. Размах крыльев 18,9 мм; 6 то же, снизу. Sesiidae снимок № 0108-2021; 7 - P. nigripennis Arita et O. Gorbunov, 2000, паратип, сверху. Sesiidae снимок № 01132021. Размах крыльев 19,3 мм (COGM); 8 - то же, снизу. Sesiidae снимок № 0114-2021; 9 - P. vitripennis Arita et O. Gorbunov, 2000, паратип, сверху. Sesiidae снимок № 0121-2021. Размах крыльев 18,4 мм (COGM); 10 — то же, снизу. Sesiidae снимок № 0122-2021. 
DIFFERENTIAL DIAGNOSIS. With their elongated legs, representatives of this genus are slightly similar to those of genus Aschistophleps Hampson, 1893. From this genus compared, Pyrophleps can be distinguished by the structure of the labial palpus (longer, directed ahead, tufted with long hairlike scales on mid joint in Pyrophleps, vs. rather shorter, turned-up, without a tuft of hair-like scales on mid joint in the genus compared), shape of the compound eyes (distinctly bean-shaped in Pyrophleps, vs. slightly bean-shaped in $A s$ chistophleps). Additionally all these genera clearly differs from each other by the shape of the valva in the male genitalia [compare Figs 23 and 25 with fig. 17b in Arita, Gorbunov, 2000].

LIFE HISTORY. Nothing is known about the host plants and the biology of the preimaginal stages of all species of this genus. Males have a mud-puddling behaviour and they can be found among bees and wasps on wet soil.

COMPOSITION. I currently include the following four species in the genus: $P$. nigripennis Arita et $\mathrm{O}$. Gorbunov, 2000 (type locality: V. Vietnam, Ninh Binh Prov., Gia Vien, Cuc Puong, $250 \mathrm{~m}$ ), P. vitripennis Arita et O. Gorbunov, 2000 (type locality: V. Vietnam, Ninh Binh Prov., Gia Vien, Cuc Puong, $250 \mathrm{~m}$ ), Pyrophleps ellawi Skowron Volponi, 2017 (type locality: Malaysia: Pahang, Merapoh, 04³9.04’ $\mathrm{N}, 102^{\circ} 01.80^{\prime}$ E", and P. zamesovi O. Gorbunov, sp.n. (type locality: Laos, Kammouang Prov., Ban Khounkham (Nahin), $18^{\circ} 13^{\prime} \mathrm{N}, 104^{\circ} 31^{\prime} \mathrm{E}, 200 \mathrm{~m}$ ).

RANGE. Oriental realm from Laos and North Vietnam in the north to Malaysia in the south.

\section{Pyrophleps zamesovi O. Gorbunov, sp.n.} Figs 1-2, 5-6, 11-24.

MATERIAL. Holotype $\sigma^{7}$ (Figs 1-2), "Laos, Kammouang Prov., / Ban Khounkham (Nahin), / 18 $8^{\circ} 13^{\prime}$ N, 104 $31^{\prime}$ E, 200 m, 28.IV.2005, / O. Gorbunov leg."; "SESIIDAE / Pictures №№ 0107-0108-2021 / Photo by O. Gorbunov"; "HOLOTYPUS O" Pyrophleps zamesovi / O. Gorbunov, 2021 / O. Gorbunov des. 2020".

Paratypes $\left(71 \bigcirc^{7} \sigma^{7}\right), 6 \sigma^{7} \sigma^{7}$, same locality as holotype, $01-$ 02.V.2002, V. Tuzov leg.; 1 o', same locality, 13.IV.2005, O Gorbunov leg.; $10 \bigcirc^{7} \sigma^{7}$, same locality, 16.IV.2005, O. Gorbunov leg. (Sesiidae pictures №№ 0083-0092-2021); $20^{7} \sigma^{7}$, same locality, 17.IV.2005, O. Gorbunov leg. (Sesiidae pictures №№ 00830092-2021); $1 \sigma^{7}$, same locality, 18.IV.2005, O. Gorbunov leg.; 10 $0^{2} O^{2}$, same locality, 19.IV.2005, O. Gorbunov leg. (Sesiidae pictures №№ 0109-0110-2021); 6 O O $^{7}$, same locality, 23.IV.2005, O Gorbunov leg.; $4 \bigcirc^{7} \odot^{7}$, same locality, 24.IV.2005, O. Gorbunov leg.; $16 \sigma^{7} \sigma^{7}$, same locality, 25.IV.2005, O. Gorbunov leg. (Sesiidae pictures №№ 0093-0096-2021); $2 \sigma^{7} \sigma^{7}$, same locality, 26.IV.2005, O. Gorbunov leg. (Sesiidae pictures №№ 0105-0106-2021) (COGM); $11 \mathrm{O}^{\mathrm{T}} \mathrm{O}^{2}$, same locality, 27.IV.2005, O. Gorbunov leg. (Sesiidae pictures №№ 0097-0104-2021) (COGM); $20^{7} \sigma^{7}$, same locality, 28.IV.2005, O. Gorbunov leg. (Sesiidae pictures №№ 0107-0108-2021).

DESCRIPTION. Male (holotype) (Figs 1-2). Alar expanse $18.9 \mathrm{~mm}$; body length $12.1 \mathrm{~mm}$; forewing $8.6 \mathrm{~mm}$; antenna $5.7 \mathrm{~mm}$.

Head with antenna dorsally black with dark violet sheen, ventrally light brown with admixture of reddish-brown scales with golden hue basally on each joint; scapus black with blueanthracite sheen; frons entirely black with greenish-violet sheen; labial palpus interior-ventrally white, exterior-dorsally mixed with black with greenish-violet sheen and reddishorange scales; vertex black with greenish-violet sheen, densely covered with dark orange scales; pericephalic hairs white laterally and orange dorsally.

Thorax with patagia black with dark violet sheen and a few reddish-orange scales laterally; tegula black with dark blue-violet sheen and a few reddish-orange scales at base of forewing; meso- and metathorax black with greenish-violet sheen; thorax laterally dark brown to black with greenishviolet sheen and a few reddish-orange and white scales medially under forewing; posteriorly dark grey-brown with blue-violet sheen covered with long white hair-like scales.

Legs with neck plate white with a few dark brown to black scales with blue-violet sheen externally; fore coxa white with a narrow, broadened basally, dark brown to black with blueviolet sheen stripe in basal half externally; fore femur entirely dark brown to black with blue-violet sheen; fore tibia dark brown to black with blue-violet sheen, dorsally with a few white scales with electric-purple hue at base and a tuft of elongated brick-red scales externally; fore tarsus ventrally dark brown to black with bronze sheen, dorsally black with blue-violet sheen and a few white scales with electric-purple hue at base of three basal tarsomeres; mid coxa white internally and dark grey-brown with bronze-purple sheen externally; mid femur black with blue-violet sheen; mid tibia dark brown to black with blue-violet sheen, dorsally with a narrow white stripe in basal half and a few brick-red elongated scales medially; spurs externally dark brown to black with blueviolet sheen, internally white; mid tarsus dark brown to black with blue-violet sheen, four basal tarsomere narrowly white basally and with a small white spot with electric-purple hue dorsally at base; hind coxa dark grey-brown with bronzepurple sheen with a few white scales internally; hind femur black with blue-violet sheen; hind tibia black with greenishblue sheen, a tuft of elongated brick-red and a few white scales medial-dorsally and brick-red scales exterior-distally; spurs externally dark brown to black with blue-violet sheen, internally white; hind tarsus black with greenish-violet sheen with a few white scales with electric-purple hue basally and brick-red elongated scales exteriorly on basal tarsomere, ventrally with a few white scales basally on three basal tarsomeres.

Forewing dorsally black with dark greenish-violet sheen; ventrally dark brown to black with dark violet sheen; transparent areas well-developed, in distal half covered with brownish semi-hyaline scales with electric-blue hue; anterior and posterior transparent areas long, exceeding level of discal spot of hindwing; external transparent area rather large, divided into ten cells between veins $\mathrm{R}_{3+4}-\mathrm{CuA}_{2}$ (cells between veins $\mathrm{R}_{5}-\mathrm{CuA}$ divided into two additional cells by a narrow scaled stripe); apical area narrow, about as broad as cilia; cilia dark brown with dark bronze sheen dorsally and bronze sheen ventrally.

Hindwing transparent; dorsally distal half covered by brownish semi-hyaline scales with electric-blue hue; veins, discal spot and outer margin black with dark violet sheen; ventrally veins, discal spot and outer margin black with dark violet sheen; discal spot narrow, reaching vein $\mathrm{M}_{3}$; outer margin narrow, about as broad as cilia; cilia dark brown with dark bronze sheen dorsally and bronze sheen ventrally, anally white.

Abdomen dorsally black with dark violet sheen; distal row of scales of tergites 3, 7 and 8 each whitish; distal row of scales of tergites 4-6 each with whitish scales laterally; ventrally abdomen dark grey-brown with greenish-violet sheen and admixture of individual whitish scales; anal tuft very small black with dark violet sheen.

Male genitalia (paratype) (genital preparation № OG006-2021) (Figs 23-24). Tegumen-uncus complex narrow laterally but broad ventrally; uncus with a semi-oval plate of long hair-like setae ventro-apically, covering tuba analis like a collar; gnathos narrow, long, distinctly protruding caudally; 
valva gradually widens towards the center, and then narrows rather sharply towards the apex, making distal half spearshaped, densely covered with short and very thin hair-like setae; saccus short but broad, about as long as vinculum, straight basally; aedeagus relatively long, about 1.2 times as long as valva; vesica with numerous, minute cornuti.

Female. Unknown.

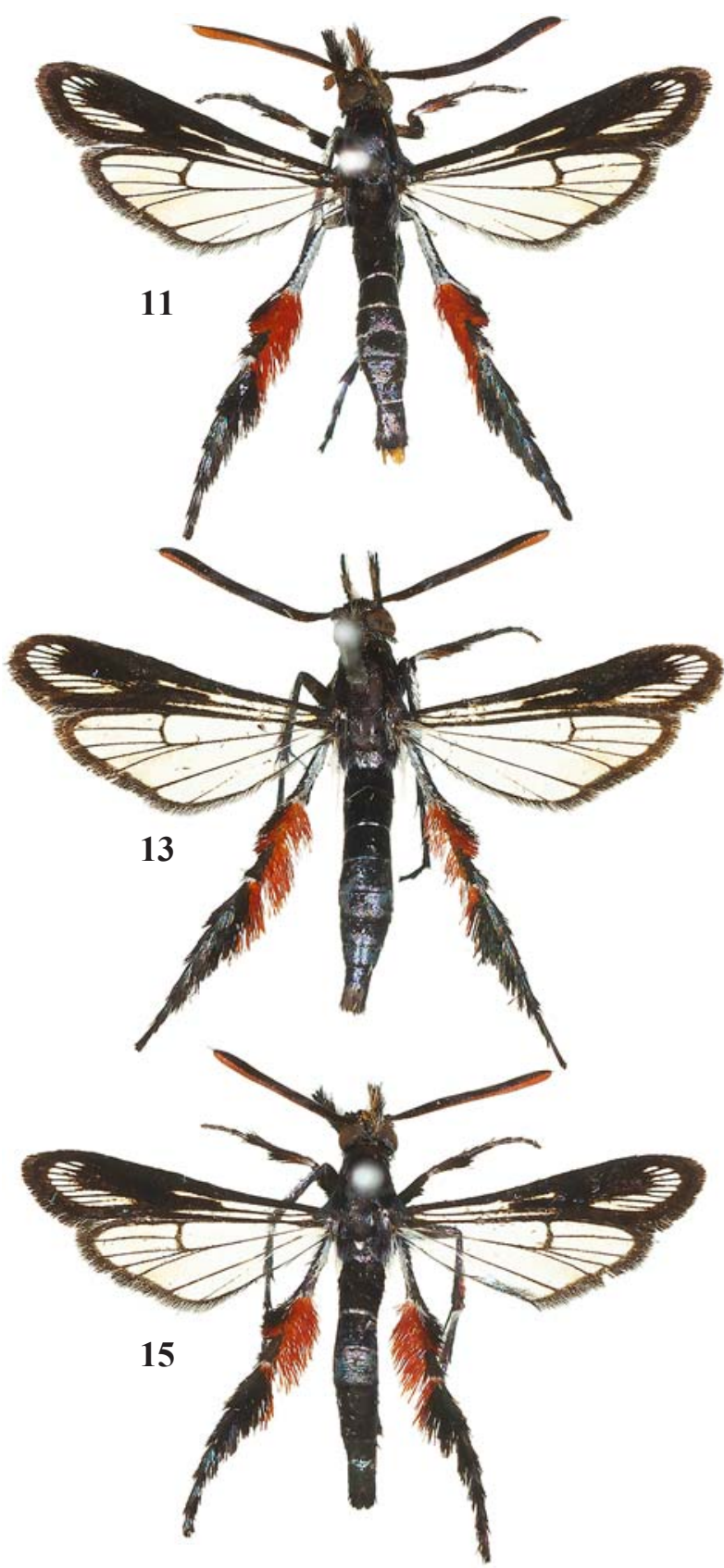

INDIVIDUAL VARIABILITY. Slightly varying in the number of reddish-orange scales on the labial palpus (Figs 12 ) and brick-red scales on the fore tibia and hind leg tuft (Figs 5-6, 11-22). In addition, the size of the transparent areas of the forewing slightly varies. Besides this, this new species is rather variable in size: alar expanse: $15.2-18.9 \mathrm{~mm}$; body length 9.0-12.0 mm; forewing 7.0-8.5; antenna 4.2-5.8 mm.

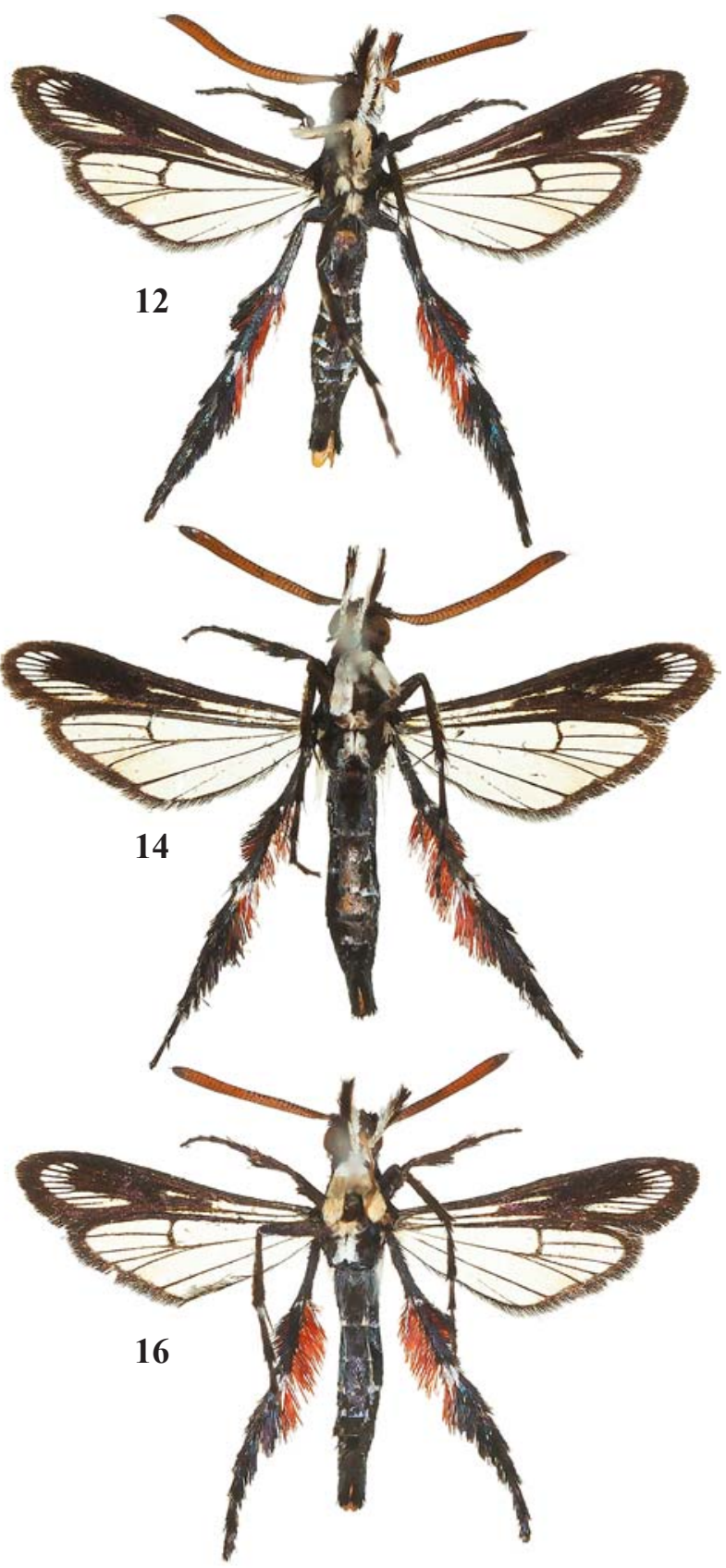

Figs 11-16. Variability of Pyrophleps zamesovi sp.n. 11 - paratype, upside. Sesiidae picture № 0083-2021. Alar expanse $16.7 \mathrm{~mm}$; 12 - ditto underside. Sesiidae picture № 0084-2021; 13 — paratype, upside. Sesiidae picture № 0085-2021. Alar expanse 17.8 mm; 14 ditto underside. Sesiidae picture № 0086-2021; 15 - paratype, upside. Sesiidae picture № 0089-2021. Alar expanse $17.0 \mathrm{~mm} ; 16$ - ditto underside. Sesiidae picture № 0090-2021.

Рис. 11-16. Изменчивость Pyrophleps zamesovi sp.n. 11 - паратип, сверху. Sesiidae снимок № 0083-2021. Размах крыльев 16,7 мм; 12 - то же, снизу. Sesiidae снимок № 0084-2021; 13 - паратип, сверху. Sesiidae снимок № 0085-2021. Размах крыльев 17,8 мм; 14 - то же, снизу. Sesiidae снимок № 0086-2021; 15 - паратип, сверху. Sesiidae снимок № 0089-2021. Размах крыльев 17,0 мм; 16 - то же, снизу. Sesiidae снимок № 0090-2021. 
DIFFERENTIAL DIAGNOSIS. By the structure of the transparent areas of the forewing this new species is closely related to $P$. vitripennis and $P$. ellawi. From the first species $P$. zamesovi sp.n. differs by the colouration of the labial palpus (exterior-dorsally dark brown with green-bronze sheen in $P$. vitripennis, $v s$. exterior-dorsally mixed with black with greenish-violet sheen and reddish-orange scales in P. zamesovi sp.n.; cp. Figs 1-2 with Fig. 4), fore tibia

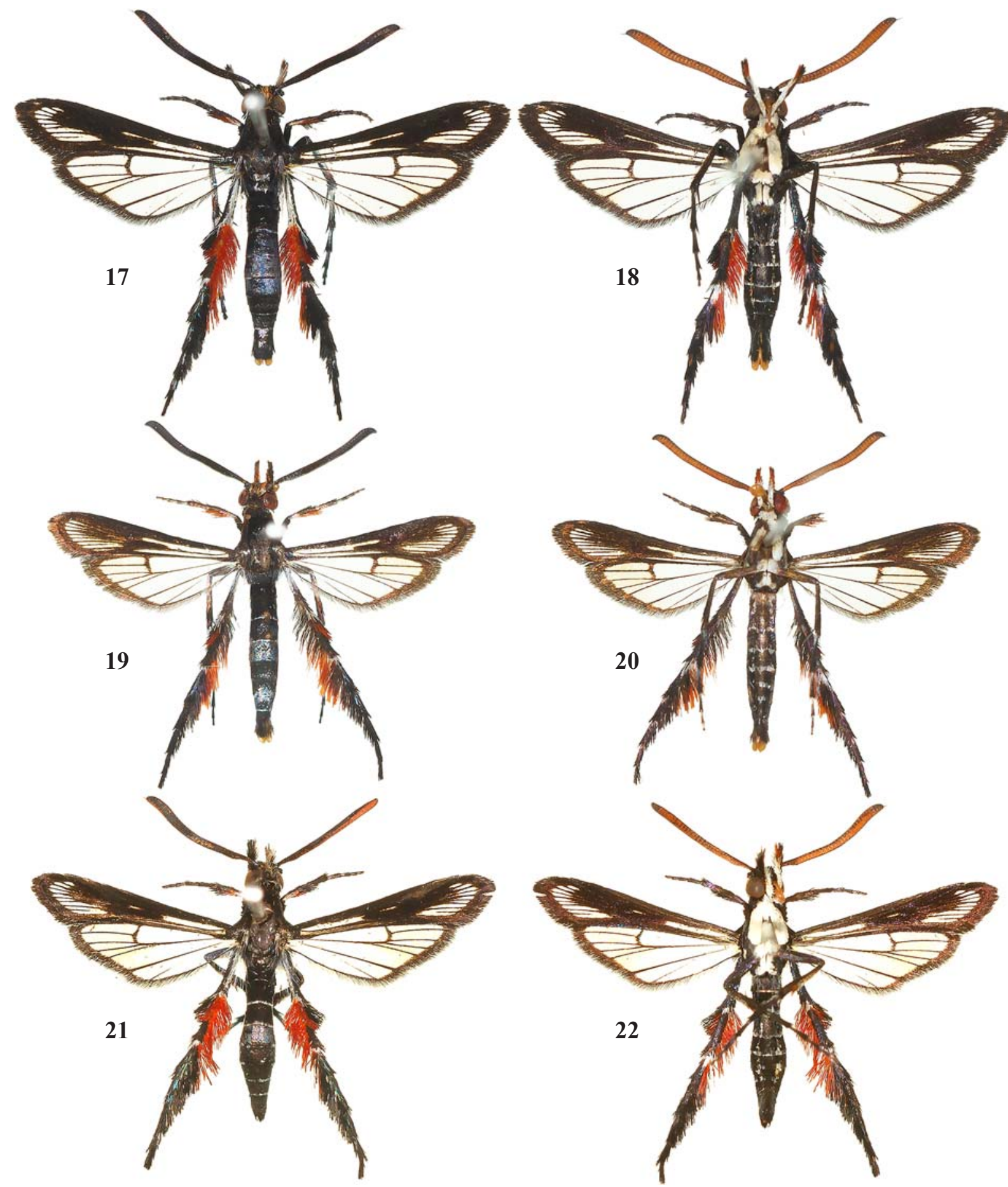

Figs 17-22. Variability of Pyrophleps zamesovi sp.n. 17 - paratype, upside. Sesiidae picture № 0093-2021. Alar expanse 17.6 mm; 18 - ditto underside. Sesiidae picture № 0094-2021; 19 — paratype, upside. Sesiidae picture № 0097-2021. Alar expanse 15.2 mm; 20 ditto underside. Sesiidae picture № 0098-2021; 21 - paratype, upside. Sesiidae picture № 0099-2021. Alar expanse $16.5 \mathrm{~mm} ; 22$ - ditto underside. Sesiidae picture № 0100-2021.

Рис. 17-22. Изменчивость Pyrophleps zamesovi sp.n. 17 - паратип, сверху. Sesiidae снимок № 0093-2021. Размах крыльев 17,6 мм; 18 - то же, снизу. Sesiidae снимок № 0094-2021; 19 - паратип, сверху. Sesiidae снимок № 0097-2021. Размах крыльев 15,2 мм; 20 - то же, снизу. Sesiidae снимок № 0098-2021; 21 — паратип, сверху. Sesiidae снимок № 0099-2021. Размах крыльев 16,5 мм; 22 - то же, снизу. Sesiidae снимок № 0100-2021. 
(dark brown to black with green-violet sheen and a large white spot dorso-basally in the species compared, $v s$. dark brown to black with blue-violet sheen, dorsally with a few white scales with electric-purple hue at base and a tuft of elongated brick-red scales externally in $P$. zamesovi sp.n.) and hind tibia (dark brown to black with strong green sheen, with a narrow white stripe interior-ventrally from base of tibia to base of mid spurs, a narrow white ring at base of mid spurs, and with brick-orange scales interior-distally in $P$. vitripennis, vs. black with greenish-blue sheen, a tuft of elongated brick-red and a few white scales medial-dorsally and brick-red scales exterior-distally in $P$. zamesovi sp.n.; cp. Figs 5-6 with Figs 9-10), and by the narrow discal spot of the hindwing (visibly broader in P. vitripennis, cp. Fig. 5 with Fig. 9). In addition, these two species are clearly distinguished by the structure of the male genitalia, especially by the shape of the valva [compare Figs 23-24 with figs 15a-d in Arita, Gorbunov, 2000a].

From $P$. ellawi, $P$. zamesovi sp.n. can be separated by the colouration of the pericephalic hairs (white with several orange scales dorsally and black ventrally in the species compared, $v s$. orange dorsally and white laterally in $P$. zamesovi sp.n.), tegula (black with blue sheen and a narrow orange inner margin in $P$. ellawi, vs. black with dark blueviolet sheen and a few reddish-orange scales at base of forewing in $P$. zamesovi sp.n.), hind tibia (black with admixture of white and brick-orange scales interior-distally in
P. ellawi, vs. black with greenish-blue sheen, a tuft of elongated brick-red and a few white scales medial-dorsally and brick-red scales exterior-distally in $P$. zamesovi sp.n.; cp. Figs 5-6, 11-22 with fig. 3 in Skowron Volponi, Volponi, 2017) and by the shape of the valva in the male genitalia [compare Fig. 23 with fig. 4 in Skowron Volponi, Volponi, 2017].

From $P$. nigripennis, $P$. zamesovi sp.n. can be easily distinguished by the colouration of the labial palpus (without reddish-orange scales in the species compared), fore tibia (dark brown to black with bronze-purple sheen, dorsally with a few pale yellow-orange scales posterior-basally in $P$. $n i$ gripennis, vs. dark brown to black with blue-violet sheen, dorsally with a few white scales with electric-purple hue at base and a tuft of elongated brick-red scales externally in $P$. zamesovi sp.n.), by the smaller transparent areas of the forewing (compare Figs 5-6 and 11-22 with Figs 7-8) and by the structure of the male genitalia (compare Figs 23-24 with Figs 25-26).

BIONOMICS. The larval host plant is unknown. The specimens of the type series exhibited a typical mud-puddling behaviour. All of them were found among bees and wasps on wet soil on the bank of a small stream.

HABITAT. The type series was collected on wet soil on the banks of the Nam Sanam stream in a primary, monsoon, semi-deciduous, lowland, tropical forest with Dipterocarpus alatus Roxb. ex G.Don, Hopea odorata Roxb., H. ferrea

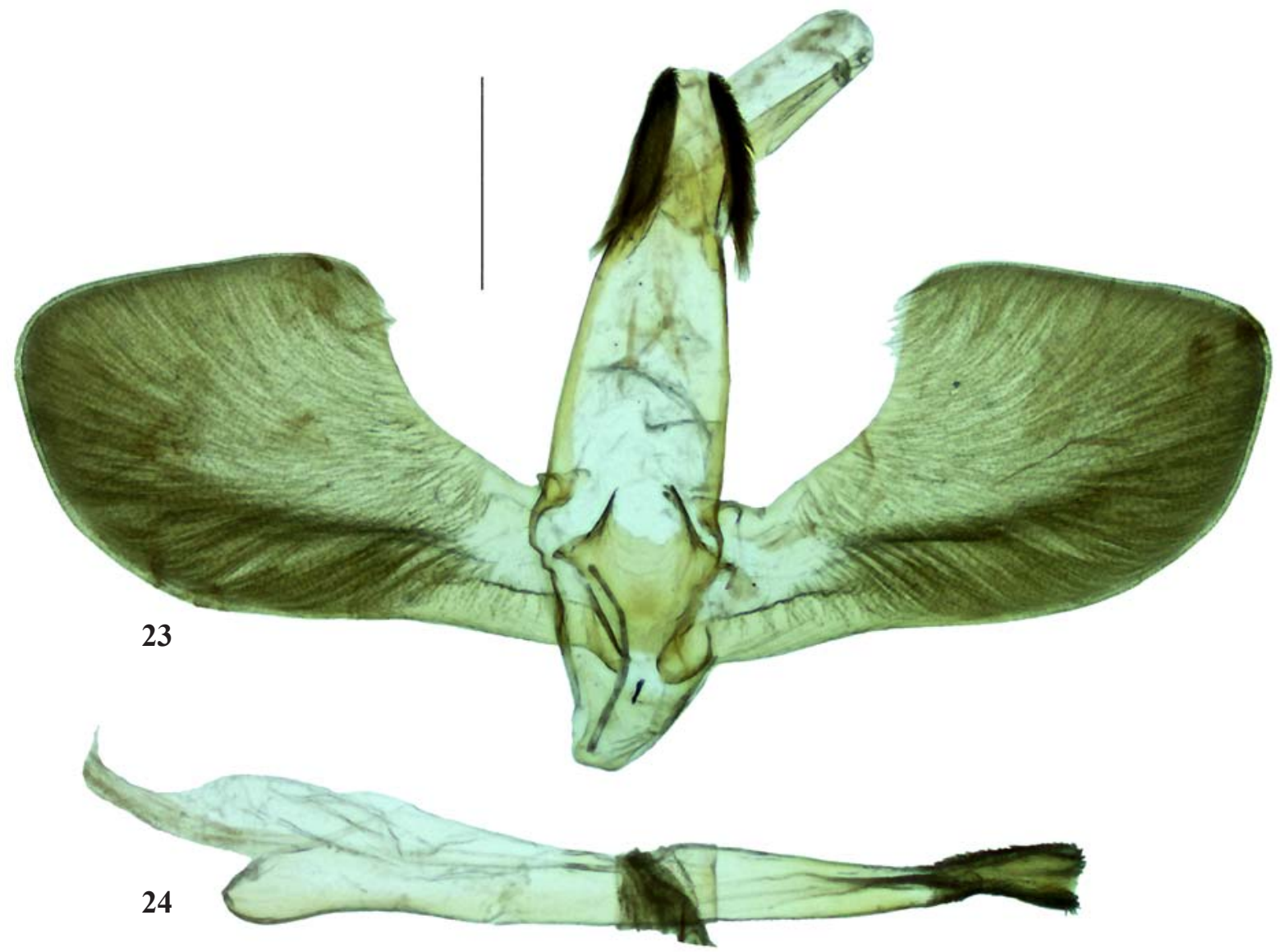

Figs 23-24. Male genitalia of Pyrophleps zamesovi sp.n. Paratype. Genital preparation № OG-006-2021; 23 — ventral view; 24 — aedeagus. Scale bar: $0.5 \mathrm{~mm}$.

Рис. 23-24. Гениталии самца Pyrophleps zamesovi sp.n. Паратип. Препарат гениталий № OG-006-2021; 23 - снизу; 24 эдеагус. Масштаб: 0,5 мм. 
Laness. (Dipterocarpaceae), Lagerstroemia cochinchinensis Pierre ex Laness. (Lythraceae), Afzelia xylocarpa (Kurz) Craib (Fabaceae) and Alstonia scholaris (L.) R. Br. (Apocynaceae) as the most dominant species.

DISTRIBUTION. The new species is known only from the type locality in Laos.

ETYMOLOGY. This new species is named after my friend Alexei Nikolaevich Zamesov (Moscow, Russia), an excellent lepidopterist who always helps me in my research.

Acknowledgements. I would like to express my cordial thanks to Mr. Alexey N. Zamesov (Moscow, Russia) for the company and help during our successful trip to Laos in 2005, Dr. Marta A. Skowron Volponi (Warsaw, Poland) for a very productive discussion about Oriental Osminiini, Dr. Vasily K. Tuzov (Moscow, Russia) for the gift of material, and Mr. Vlad V. Proklov (London, England) for carefully checking the English of an advanced draft.

The study was conducted using the equipment of the Joint Usage Center "Instrumental methods in ecology" at the A.N. Severtsov Institute of Ecology and Evolution, Russian Academy of Sciences (Moscow, Russia).

\section{References}

Arita Y., Gorbunov O.G. 2000a. Notes on the tribe Osminiini (Lepidoptera, Sesiidae) from Vietnam, with descriptions of new taxa // Trans. Lepid. Soc. Jpn. Vol.51. No.1. P.49-74.

Arita Y., Gorbunov O.G. 2000b. On the knowledge of the genus Chamanthedon Le Cerf, 1916 (Lepidoptera, Sesiidae, Osminiini) of Vietnam and adjacent countries // Trans. Lepid. Soc. Jpn. Vol.51. No.3. P.205-214.

Arita Y., Gorbunov O.G. 2001. Sesiidae of Taiwan. I. The Tribes Tinthiini, Similipepsini, Paraglosseciini, Pennisetiini, Paranthrenini and Cissuvorini // Jpn. J. syst. Ent. Vol.7. No.2. P.131-188.

Arita Y., Gorbunov O.G. 2002. Sesiidae of Taiwan. II. The tribes Osminiini, Melittiini and Sesiini // Jpn. J. syst. Ent. Vol.8. No.2. P.199-241.

Arita Y., Gorbunov O.G. 2003. New taxa of wasp-waisted clearwing moths (Lepidoptera, Sesiidae, Similipepsini) from Vietnam // Trans. Lepid. Soc. Jpn. Vol.54. No.1. P.11-19.

Arita Y., Kallies A., Yata N. 2019. A large hornet mimic clearwing moth of the genus Lamellisphecia Kallies \& Arita, 2004 (Lepidoptera, Sesiidae) from Nanling, Guangdong, southern China // Zootaxa. Vol.4706. No.3. P.477-482.

Gorbunov O.G. 2015a. A new species of the genus Anthedonella O. Gorbunov et Arita, 1999 from the island of Siberut, Mentawai, Indonesia // Far Eastern Entomologist. No.299. P.11-17.
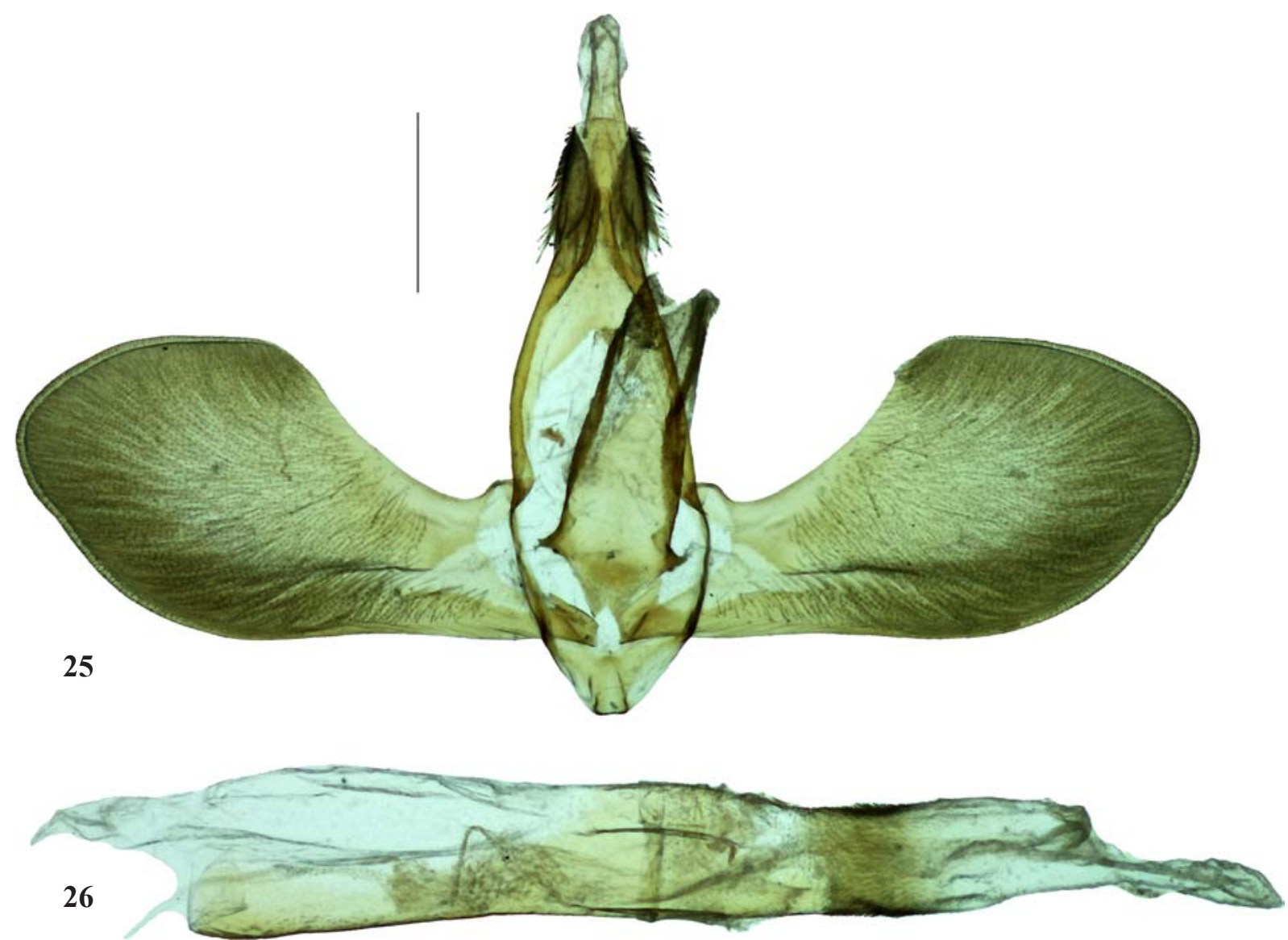

Figs 25-26. Male genitalia of Pyrophleps nigripennis Arita et O. Gorbunov, 2000. S. Vietnam, Dong Nai, Cat Tien National Park, $11^{\circ} 26.439^{\prime} \mathrm{N}, 107^{\circ} 24.747^{\prime} \mathrm{E}, 150 \mathrm{~m}, 23 . \mathrm{IV} .2018$, O. Gorbunov leg. (COGM). Genital preparation № OG-008-2021; 25 — ventral view; 26 - aedeagus. Scale bar: $0.5 \mathrm{~mm}$.

Рис. 25-26. Гениталии самца Pyrophleps nigripennis Arita et O. Gorbunov, 2000. Ю. Вьетнам, Донг Най, Национальный парк Кат Тьен, $11^{\circ} 26.439^{\prime}$ с.ш., $107^{\circ} 24.747^{\prime}$ в.д., 150 м, 23.IV.2018, О. Горбунов leg. (COGM). Препарат гениталий № OG-008-2021; 25 - вид снизу; 26 - эдеагус. Масштаб: 0,5 мм. 
Gorbunov O.G. 2015b. Clearwing moths (Lepidoptera: Sesiidae) of Laos. I. Akaisphecia melanopuncta O. Gorbunov, Arita, 1995 (Sesiidae: Sesiinae: Osminiini) // Tropical Lepid. Research. Vol.25. No.2. P.98-100.

Gorbunov O.G. 2018. A new species of the genus Taikona Arita et O. Gorbunov, 2001 from the Malay Peninsula (Lepidoptera Sesiidae) // Russian Entomol. J. Vol.27. No.3. P.293-296.

Gorbunov O.G. 2021a. A new genus of the tribe Osminiini (Lepidoptera: Sesiidae) from the Oriental Region // Far Eastern Entomologist. In press.

Gorbunov O.G. 2021b. Review of the genus Aschistophleps Hampson, 1893 (Lepidoptera, Sesiidae) of Laos // Zootaxa. In press.

Gorbunov O.G., Arita Y. 2000. Study on the Synanthedonini (Lepidoptera, Sesiidae) of Vietnam // Jpn. J. syst. Ent. Vol.6. No.1. P.85-113.

Gorbunov O.G., Arita Y. 2001. A new species of the genus Ravitria Gorbunov \& Arita (Lepidoptera, Sesiidae) from Yunnan, China // Trans. Lepid. Soc. Jpn. Vol.52. No.4. P.245-249.

Gorbunov O.G., Arita Y. 2002. A new species of the genus Aschistophleps Hampson (Lepidoptera, Sesiidae) from Vietnam // Trans. Lepid. Soc. Jpn. Vol.53. No.4. P.193-196.

Gorbunov O.G., Arita Y. 2005. A new genus and two new species of Synanthedonini (Lepidoptera, Sesiidae) from the Oriental Region // Tinea (Supplement 3). P.86-95.

Gorbunov O.G., Arita Y. 2018. A new species of the genus Sazonia O. Gorbunov \& Arita, 2001 from Vietnam (Lepidoptera: Sesiidae) // Zootaxa. Vol.4527. No.4. P.595-599.

Gorbunov O.G., Arita Y. 2019. A new species of the genus Taikona O. Gorbunov \& Arita, 2001 from Vietnam (Lepidoptera: Sesiidae) // Zootaxa. Vol.4624. No.1. P.137-141.

Gorbunov O.G., Arita Y. 2020a. A new species of the genus Toleria Walker, 1865 ["1864"] from Vietnam, with a catalogue of Asian Cissuvorini (Lepidoptera: Sesiidae) // Zootaxa. Vol.4802. No.2. P.349-360.

Gorbunov O.G., Arita Y. 2020b. A new species of the genus Nokona Matsumura, 1931 (Lepidoptera: Sesiidae) from Vietnam // Russian Entomol. J. Vol.29. No.2. P.195-198.

Gorbunov O.G., Arita Y. 2020c. Two new species of the genus Nokona Matsumura, 1931 (Lepidoptera, Sesiidae) from Vietnam // Far Eastern Entomologist. No.412. P.1-12.

Kallies A., Arita Y. 2001. The Tinthiinae of North Vietnam (Lepidoptera, Sesiidae) // Jpn. J. syst. Ent. Vol.52. No.3. P.187-235.

Kallies A., Arita Y. 2004a. A survey of the clearwing moths of the tribe Sesiini (Lepidoptera, Sesiidae) from Vietnam and adjacent countries with a synopsis of the Oriental Sesiini fauna // Tinea. Vol.18. No.1. P.65-95.

Kallies A., Arita Y. 2004b. New taxa and records of clearwing moths of the tribe Melittiini (Lepidoptera, Sesiidae) from Vietnam // Jpn. J. syst. Ent. Vol.10. No.2. P.193-209.

Kallies A., Arita Y. 2005. Systematic position of the genus $D a$ sysphecia (Lepidoptera, Sesiidae, Cissuvorini) with descriptions of two new bumble bee mimicking species from northern Vietnam // Trans. Lepid. Soc. Jpn. Vol.56. No.2. P.85-92.

Kallies A., Arita Y. 2006. New wasp-waisted clearwing moths (Lepidoptera, Sesiidae, Tinthiinae) from Vietnam and Taiwan // Trans. Lepid. Soc. Jpn. Vol.57. No.4. P.371-377.

Kallies A., Ogane H., Yata N. 2020. A new species of the genus Toleria Walker, [1865] from northern Vietnam and Laos with establishment of a generic synonymy of Cissuvorini (Lepidoptera, Sesiidae) // Zootaxa. Vol.4728. No.1. P.123-132.

Kallies A., Štolc V. 2018. A new species of Aschistophleps from Thailand and Laos, with a new generic synonymy (Lepidoptera, Sesiidae) // Zootaxa. Vol.4446. No.4 P.596-600.

Pühringer F., Kallies A. 2004. Provisional check list of the Sesiidae of the world (Lepidoptera: Ditrysia) // Mitt. Ent. Arb. gem. Salzkammergut. Bd.4. S.1-85.

Pühringer F., Kallies A. 2021. Checklist of the Sesiidae of the world (Lepidoptera: Ditrysia). Available from: http://www.sesiidae.net/ Checklst.htm (accessed 12 May 2021)

Skowron Volponi M. 2020. A vivid orange new genus and species of Braconid-mimicking clearwing moth (Lepidoptera: Sesiidae) found puddling on Plecoptera exuviae// Insects. Vol.11. No.425. P.1-9.

Skowron M.A., Munisamy B., Hamid S.B.A., Wêgrzyn G. 2015. A new species of clearwing moth (Lepidoptera: Sesiidae: Osminiini) from Peninsular Malaysia, exhibiting bee-like morphology and behaviour // Zootaxa. Vol.4032. No.4. P.426-434.

Skowron Volponi M.A., Volponi P. 2017. A new species of waspmimicking clearwing moth from Peninsular Malaysia with DNA barcode and behavioural notes (Lepidoptera, Sesiidae) // ZooKeys. Vol.692. P.129-139.

The Plant List, 2013. Version 1.1. Published on the Internet; http:// www.theplantlist.org/ (accessed 24 April 2021).

Xu H.-M., Arita Y., Chen B., Wang M. 2015. Description of Pyrophleps bicella (Lepidoptera: Sesiidae), a new Chinese species of clearwing moth. Florida Entomologist. Vol.98. No.1. P.149-151. 